\title{
Characterization of the inter-annual, seasonal, and diurnal variations of condensation particle concentrations at Neumayer, Antarctica
}

\author{
R. Weller ${ }^{1}$, A. Minikin ${ }^{2}$, D. Wagenbach ${ }^{3}$, and V. Dreiling , $^{*}$ \\ ${ }^{1}$ Alfred Wegener Institute for Polar and Marine Research, Am Handelshafen 12, 27570 Bremerhaven, Germany \\ ${ }^{2}$ Deutsches Zentrum für Luft- und Raumfahrt (DLR), Institut für Physik der Atmosphäre, Oberpfaffenhofen, 82234 Weßling, \\ Germany \\ ${ }^{3}$ Institut für Umweltphysik, University Heidelberg, Im Neuenheimer Feld 229, 69120 Heidelberg, Germany \\ ${ }^{4}$ Institut für Physik der Atmosphäre, Universität Mainz, 55099 Mainz, Germany \\ *now at: Deutsches Zentrum für Luft- und Raumfahrt (DLR), Flugexperimente, Oberpfaffenhofen, 82234 Weßling, Germany
}

Received: 29 June 2011 - Published in Atmos. Chem. Phys. Discuss.: 21 July 2011

Revised: 23 November 2011 - Accepted: 9 December 2011 - Published: 21 December 2011

\begin{abstract}
Continuous condensation particle (CP) observations were conducted from 1984 through 2009 at Neumayer Station under stringent contamination control. During this period, the CP concentration (median $258 \mathrm{~cm}^{-3}$ ) showed no significant long term trend but exhibited a pronounced seasonality characterized by a stepwise increase starting in September and reaching its annual maximum of around $10^{3} \mathrm{~cm}^{-3}$ in March. Minimum values below $10^{2} \mathrm{~cm}^{-3}$ were observed during June/July. Dedicated time series analyses in the time and frequency domain revealed no significant correlations between inter-annual CP concentration variations and atmospheric circulation indices like Southern Annular Mode (SAM) or Southern Ocean Index (SOI). The impact of the Pinatubo volcanic eruption and strong El Niño events did not affect $\mathrm{CP}$ concentrations. From thermodenuder experiments we deduced that the portion of volatile (at $125^{\circ} \mathrm{C}$ ) and semi-volatile (at $250^{\circ} \mathrm{C}$ ) particles which could be both associated with biogenic sulfur aerosol, was maximum during austral summer, while during winter non-volatile sea salt particles dominated. During September through April we could frequently observe enhanced concentrations of ultrafine particles within the nucleation mode (between $3 \mathrm{~nm}$ and $7 \mathrm{~nm}$ particle diameter), preferentially in the afternoon.
\end{abstract}

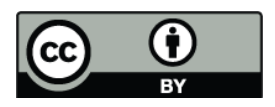

Correspondence to: $\mathrm{R}$. Weller (rolf.weller@awi.de)

\section{Introduction}

Greenhouse gases and aerosols are atmospheric trace compounds determining decisively the radiation balance of the Earths' atmosphere (Forster et al., 2007), hence thorough knowledge about atmospheric cycling are pivotal to predict their impact on global climate (Haywood and Boucher, 2000; Ramanathan et al., 2001; Hatzianastassiou et al., 2004; Forster et al., 2007). Unlike most of the important greenhouse gases $\left(\mathrm{CO}_{2}, \mathrm{CH}_{4}, \mathrm{~N}_{2} \mathrm{O}\right)$, aerosols stand out due to short atmospheric lifetimes typically in the range of a few days, entailing a striking temporal and spatial concentration and ultimately radiation forcing variability (Raes et al., 2000; Ramanathan et al., 2001). In this regard the nearly completely ice covered Antarctic continent is a particular interesting case: Primary aerosol sources like sea spray, mineral dust, or soot, as well as aerosol sources due to gas to particle conversion (secondary aerosol) are virtually absent on this continent, apart from some insular rocky regions (on the Antarctic peninsula, in the coastal dry valleys and on high mountain ranges) and volcanic activity of Mt. Erebus. Hence, as pointed out in a noted review about Antarctic aerosol by Shaw (1988), it is remarkable that submicrometer particles are present throughout the Antarctic air, in spite of distant source regions and efficient wet depositional removal within the persistent circumpolar low pressure system. In fact, the Southern Ocean remains as being by far the dominant source to the Antarctic aerosol body, making atmospheric sea salt and biogenic sulfur to the major aerosol components (Wagenbach, 1996; Minikin et al., 1998; Preunkert et al., 2007). Nowadays, minor anthropogenic

Published by Copernicus Publications on behalf of the European Geosciences Union. 
emissions arising from fossil fuel combustion during research and tourism activities might be considered as well (Shirsat and Graf, 2009).

Particle concentrations are usually measured by condensation particle counters (CPC), which optically detect and count each particle above a given particle size (typically $10 \mathrm{~nm}$ diameter) after condensation growth in supersaturated butanol vapour (Agarwal and Sem, 1980). Hence, condensation particle (CP) concentration measured in this way represent total particle numbers concentrations above the given cut-off size. So far, continuous long-term studies on particle or CP concentrations in Antarctica were restricted to Amundsen-Scott Base, South Pole (Samson et al., 1990; Bodhaine, 1996) and coastal Georg von Neumayer $\left(70^{\circ} 37^{\prime} \mathrm{S}\right.$, $8^{\circ} 22^{\prime} \mathrm{W}$; Jaenicke et al., 1992), while from Syowa $\left(69^{\circ} 00^{\prime} \mathrm{S}\right.$, $39^{\circ} 35^{\prime} \mathrm{E}$ ) at least year-round $\mathrm{CP}$ measurements for the period 1976-1978 are available (Ito, 1985). There is a lack of dedicated investigations concerning the climatology, i.e. longterm trend and inter-annual variability of particle concentrations and their links to climate factors, e.g. the development of southern atmospheric circulation pattern like the Southern Annular Mode (SAM), Southern Ocean Index (SOI) and El Niño teleconnection.

Another pivotal point in view of aerosol budget is the role of new particle formation (nucleation) especially in remote marine and Polar Regions. Recent efforts with a global aerosol microphysics model, evaluated along with observations from 36 sites around the world (including Neumayer), revealed the importance of secondary aerosol formation, which is usually attended by nucleation, in these regions (Spracklen et al., 2010). Particle concentrations in the remote marine boundary layer (MBL) are generally rather constant despite efficient removal processes (e.g. Covert et al., 1996), indicating significant new particle formation to balance this loss. Although photo-oxidation of algae derived dimethylsulfide (DMS) is a potential secondary aerosol source in the MBL, new particle formation seems to be mainly connected with entrainment of free tropospheric air but seems marginal within the remote MBL itself due to permanently present large aerosol surface areas (primarily by already present sulfate aerosol and sea spray) acting as a condensation sink for low volatile supersaturated gases (Raes, 1995; Covert et al., 1996; Capaldo et al., 1999; Heintzenberg et al., 2004). Nevertheless, there is some observational evidence of considerable particle nucleation within the MBL in regions with enhanced DMS flux (Davison et al., 1996; O’Dowd et al., 1997; Clarke et al., 1998). In this context, the Southern Ocean surrounding the Antarctic continent shows striking biological activity during polar spring and summer (Gabric et al., 2005; Korhonen et al., 2008; Lana et al., 2011), provoking pronounced formation of biogenic sulfur aerosol (Minikin et al., 1998; Preunkert et al., 2007). Accordingly, nucleation events have also been reported from coastal Syowa (Ito, 1993) and the rather coastal Finnish Antarctic station Aboa $\left(73^{\circ} 03^{\prime} \mathrm{S}, 13^{\circ} 25^{\prime} \mathrm{W}, 130 \mathrm{~km}\right.$ away from coastline; Koponen et al., 2003), while at continental South Pole comparable events had to be typically associated with the impact local pollution during calm weather conditions (Park et al., 2004). In fact, all these investigations represent elaborate case studies accomplished with considerable experimental effort, but were temporally restricted to a few months during Antarctic polar summer.

In view of these previous investigations and the addressed open questions, the main purpose of this paper is investigating in detail the meanwhile $29 \mathrm{yr}$ CP record available from Neumayer Station. The CP record is mainly backed-up by concurrent aerosol sampling dedicated for determination of its ionic composition. The results from the latter investigations have been discussed in detail (Weller et al., 2011). We will first focus on long-term changes of CP concentrations and evaluate the Neumayer observations in the time and frequency (spectral) domain along with corresponding time series of sea ice extent, Southern Annular Mode, and Southern Ocean Index. In a second step seasonality and diurnal cycle of $\mathrm{CP}$ concentrations will be investigated and tied to the ionic composition of the aerosol. Finally we will examine observed nucleation mode particles between $3 \mathrm{~nm}$ and $7 \mathrm{~nm}$ particle diameter, discuss their seasonality, diurnal cycle, as well as their relevance concerning the $\mathrm{CP}$ budget at Neumayer.

\section{Experimental techniques and data evaluation methods}

\subsection{Site description and instrumentation}

Measurements were conducted at the Air Chemistry Observatory, Neumayer Station (NM, 70 $39^{\prime} \mathrm{S}, 8^{\circ} 15^{\prime} \mathrm{W}$; http:// www.awi.de/en/go/air \chemistry_observatory) which participates in the Global Atmosphere Watch (GAW) programme. To ensure contamination free air sampling, the Air Chemistry Observatory is situated in the clean air district approximately $1.5 \mathrm{~km}$ south of NM. Due to the fact that northerly wind directions are very rare, contamination from the base can be excluded for most of the time. Additionally, the power supply $(20 \mathrm{~kW})$ is provided by cable from the main station. For a detailed description of the measuring site, meteorological conditions, contamination free sampling, and analysis of the aerosol samples we refer to Wagenbach et al. (1988), König-Langlo et al. (1998) and Weller et al. (2008). A ventilated electro-polished stainless steel inlet stack (total height about $8 \mathrm{~m}$ above the snow surface) with a $50 \%$ aerodynamic cut-off diameter around 7-10 $\mu \mathrm{m}$ at wind velocities between 4-10 $\mathrm{m} \mathrm{s}^{-1}$ (determined with an aerodynamic particle sizer TSI, type APS 3321) supplied the experiments with ambient air. Continuous test measurements with two condensation particle counters of identical technical specification were performed through October 2002, one plugged to the inlet stack the other sampling directly ambient air from outside. 
No bias or offset between the measured signals ( 5 min resolution) could be detected and the values agreed within $\pm 5 \%$, except few sporadic spikes. The length of the inlet tubes from the stack to the CPCs was around $70 \mathrm{~cm}$ and we exclusively used silicone conductive tubes from TSI, $1 / 4$ inner diameter. We refrained from a loss correction, because this is highly dependent on the particle diameter (especially for $D_{\mathrm{p}}<10 \mathrm{~nm}$ ) and thus only reasonable in connection with a differential particle analyser (DMA). Hence calculated ultrafine particle values (see below) may be regarded as lower limits.

Concerning the question how representative our $\mathrm{CP}$ record might be, the characteristics of the boundary layer at this site needs to be considered. As typical for Antarctica, surface inversions are common which could extend up to about $2 \mathrm{~km}$ during winter while from November to February inversions are rare and confined to heights less than $1 \mathrm{~km}$ (KönigLanglo et al., 1998). Frequent stormy weather conditions usually destroy the stratification of the lower troposphere. Due to the stability of the free atmosphere above the boundary layer the typical height of the stable boundary layer (SBL), defined as the lowest altitude above ground where turbulent mixing ceased, ranged between $10 \mathrm{~m}$ and $50 \mathrm{~m}$ (Handorf, 1996).

Condensation particle measurements started at NM in January 1982. Table 1 gives an overview of the employed particle counters. Up to December 1989 a condensation particle counter (Thermo Systems Inc., TSI, type CPC 3020; nominal $50 \%$ cut-off particle diameter $D_{\mathrm{p}(50 \%)}$ of $10 \mathrm{~nm}$ ) provided particle number concentrations typically with hourly resolution (Jaenicke et al., 1992), henceforward in $150 \mathrm{~s}$ resolution. From 1990 ongoing, a CPC 3760, CPC 3022, or CPC 3022A (all from TSI) were optionally in use, characterized by a lower $D_{\mathrm{p}(50 \%)}$ of $7 \mathrm{~nm}$. In order to assess the contribution of particles within the nucleation mode between $3 \mathrm{~nm}$ and $7 \mathrm{~nm}$ particle diameter $\left(D_{\mathrm{p}}\right)$, we employed an ultrafine particle counter (Stolzenburg and McMurry, 1991) with a $D_{\mathrm{p}(50 \%)}$ of $3 \mathrm{~nm}$ (TSI Model CPC 3025A). This instrument was simultaneously run in $150 \mathrm{~s}$ resolution with the CPC 3022/3022A from February 1996 ongoing, except for the years 1999, 2009 and between April 2006 and December 2007 (see Table 1). Routinely, calibration of all CPcounters was performed by the manufacturer in a $2 \mathrm{yr}$ cycle, except for the CPC 3025A which was calibrated in 1999 and 2006. Usually there was an overlap period of one year when a freshly calibrated CPC is run for inter-comparison in parallel with the other one. The performance of the CPC $3025 \mathrm{~A}$ can just as well be checked by comparing the signal during winter (when nucleation events are absent) with a CPC 3022A. Only from 2005 through 2007 when the CPC 3022 and 3022A were involved in the thermodenuder experiment, we resign the calibration interruption for this period. As far as our experience goes, a 2 yr calibration cycle is reliable anyway and we never noticed any significant off-set after calibration. This may be due to the fact, that the mea-
Table 1. Listing of operation periods of the different particle counters types at Neumayer Station.

\begin{tabular}{llrr}
\hline Period & Instrument & $\begin{array}{r}\text { Temporal } \\
\text { resolution }\end{array}$ & $\begin{array}{r}50 \% \text { cut-off } \\
\text { diameter } \\
\left(D_{\mathrm{p}(50 \%)}\right)\end{array}$ \\
\hline Jan 1982-Dec 1989 & CPC 3020 & $60 \mathrm{~min}$ & $10 \mathrm{~nm}$ \\
Jan 1990-Jun 1992 & CPC 3760 & $60 \mathrm{~min}$ & $7 \mathrm{~nm}$ \\
Jul 1992-Dec 1994 & CPC 3760 & $150 \mathrm{~s}$ & $7 \mathrm{~nm}$ \\
Jan 1995-Dec 2008 & CPC 3022(A) & $150 \mathrm{~s}$ & $7 \mathrm{~nm}$ \\
Feb 1996-Dec 1998 & CPC 3025A & $150 \mathrm{~s}$ & $3 \mathrm{~nm}$ \\
Jan 2000-Apr 2006 & CPC 3025A & $150 \mathrm{~s}$ & $3 \mathrm{~nm}$ \\
Jan 2008 ongoing & CPC 3025A & $150 \mathrm{~s}$ & $3 \mathrm{~nm}$ \\
\hline
\end{tabular}

sured particle concentration range was generally well below $5000 \mathrm{~cm}^{-3}$ even in the highest temporal resolution and thus definitely within the single particle counting range. About every month a flow calibration of the CPCs was conducted by a Gilibrator air flow calibration system. Based on hourly mean values, the typical standard deviation of the recorded flow for a period of one year was $0.078 \mathrm{~cm}^{3} \mathrm{~s}^{-1}$ (nominal flow value: $5.0 \mathrm{~cm}^{3} \mathrm{~s}^{-1}$ ).

Particle concentration measurements were complemented by particle volatility studies starting from January 2003 through December 2007. In this case a thermodenuder (TD) was deployed according to Wehner et al. (2002), comprising a controlled heated inlet line coupled to one the CPC 3022 while the other one was connected to the unheated inlet. The TD temperatures were set on a daily basis alternating to $125^{\circ} \mathrm{C}$ and $250^{\circ} \mathrm{C}$ to characterize particle volatility. This method allowed a classification of the aerosol in volatile, semi-volatile, and non-volatile (refractory) compounds and provided a crude but fast characterization of its chemical habit: sulfuric acid aerosol is volatile above $125^{\circ} \mathrm{C}$ and ammonium sulfate above $250^{\circ} \mathrm{C}$ (semi-volatile), while soot (black carbon), mineral dust, and sea salt remain non-volatile above $250^{\circ} \mathrm{C}$ (Burtscher et al., 2001). For about $15 \mathrm{~min}$ every day a diffusion screen separator (Particle Size Selector Model 376060, TSI; further information see Feldpausch et al., 2006) was switched in front of the heated inlet to assess the volatility of particles below a defined diameter (in our case $\mathrm{D}_{p}<40 \mathrm{~nm}$ ). Periodic comparative measurements with both CPC 3022 instruments simultaneously connected with an unheated inlet showed a typical scatter between both signals within $5 \%$ to $10 \%$ but did not indicate any significant bias.

Particle measurements were accompanied by bulk aerosol sampling for chemical analyses. We refer here to Weller et al. (2011) who described the climatology of the ionic composition of the aerosol at Neumayer derived from continuous high volume sampling since 1983 with a temporal resolution of 7-14 days. From October 2003 through December 2010 (except for the period between February 2007 and February 
2008), aerosols were also sampled for $24 \mathrm{~h}$ time periods using a 2-stage PFA (polyfluoralkoxy-copolymer) filter holder system, including a teflon and a nylon (Nylasorb) filter in series (all $1 \mu \mathrm{m}$ pore size). Generally, samples were analyzed by ion chromatography for methane sulfonate $\left(\mathrm{CH}_{3} \mathrm{SO}_{3}^{-}\right.$, $\mathrm{MS}), \mathrm{Cl}^{-}, \mathrm{Br}^{-}, \mathrm{NO}_{3}^{-}, \mathrm{SO}_{4}^{2-}, \mathrm{Na}^{+}, \mathrm{NH}_{4}^{+}, \mathrm{K}^{+}, \mathrm{Mg}^{2+}$, and $\mathrm{Ca}^{2+}$. For details concerning aerosol filter handling and analyses we refer to Piel et al. (2006) and Weller et al. (2011).

Throughout this work the time is given in UTC, corresponding to a shift of +32 min relative to the solar time. Condensation particle and ionic concentrations are given in particles $\mathrm{cm}^{-3}$ and $\mathrm{ng} \mathrm{m}^{-3}$, respectively, referring to SPT $\left(273.16^{\circ} \mathrm{K}\right.$ and $\left.1013 \mathrm{hPa}\right)$.

\subsection{Data evaluation methods}

First, all data points recorded under potential contamination conditions, indicated by wind directions within a $330^{\circ}-30^{\circ}$ sector and/or wind velocities below $2.0 \mathrm{~m} \mathrm{~s}^{-1}$ were removed. From 1996 on-going, black carbon concentrations were continuously monitored by an aethalometer (Magee Scientific, type AE10, since March 2006 in addition by a Multi Angle Absorption Photometer, MAAP model 5012, Thermo Electron Corp.), providing a supplemental criterion for local pollution. In such cases BC concentrations levels exceeded $100 \mathrm{ng} \mathrm{m}^{-3}$ by far. Note that the actual data loss due to potential contamination was less than $2 \%$.

Analyses of the CP concentration time series in terms of inter-annual variability, long-term trend behaviour, and correlations with atmospheric circulation indices were based on evaluation methods previously applied to our ionic composition records of NM aerosol samples (Weller et al., 2011). The correlations with circulation indices includes Southern Annular Mode (SAM, retrieved from http://jisao.washington. edu/data/aao/slp/) and Southern Ocean Index, (SOI, retrieved from http://www.cdc.noaa.gov/data/climateindices/) as well as sea ice extent (SIE, retrieved from National Snow and Ice Data Center, NSIDC, http://nsidc.org/). Thus, we refer to Weller et al. (2011) and accompanying Supporting Information therein for a more detailed presentation of the application of the used statistical methods. The CP time series was analyzed in the time and frequency domain and trend estimates were based on the nonparametric rank-order Mann-Kendall test (Hirsch et al., 1982). Due the fact that $\mathrm{CP}$ concentration variability is best described by a lognormal distribution, all time series analyses were additionally performed using the logarithms of the original data set. We restrict our evaluation to variability on the time scale larger than one year and thus averaged the original signal over nonoverlapping "bins" of equal time intervals $\tau$ of one month. Furthermore, normalized anomalies $\mathrm{X}(\tau)$ for each running time step $\tau$ within the observation period were calculated according to Eq. (1):

$\mathrm{X}(\tau)=\left[x(i j)-<x_{i}>\right] / \sigma_{i}$
Where $x(i j)$ is the mean of the measured parameter $\mathrm{X}$ for the month $i$ for a given year $\left.j,<x_{i}\right\rangle$ and $\sigma_{i}$ are the mean and standard deviation (or its respecting logarithm) over all years for this month. We used Monte Carlo Singular Spectrum Analysis (MC-SSA; e.g. Ghil et al., 2002) to generate data adaptive filtered representations of the CP record which was further analysed by the Multitaper Method (MTM; Percival and Walden, 1993). For all employed statistical methods, we generally refer to $p=0.05$ significance level if not noted otherwise.

\subsection{Data presentation}

Figure 1 summarizes the results of $26 \mathrm{yr}$ continuous CP measurements at NM, starting in 1984 (Supplement data are available at http://doi.pangaea.de/10.1594/PANGAEA. 771194. There are several points to note: (1) we present daily means of the original data and omitted results before 1984 because for this period data loss by instrumental and data acquisition malfunctions appeared inacceptable for our purpose. (2) Particularly before 1989 (but also in 1990) there were still some severe data gaps and the CPC 3020 in operation had a higher cut-off diameter compared to the CP counters employed from then on (Table 1). (3) From 24 February 2009 through 04 February 2010 only an UCPC 3025A was in operation with a lower particle diameter cut-off. Thus these data are biased to higher values, especially during late summer when ultrafine particle concentrations are highest (see below).

Condensation particle concentrations are well represented by the lognormal probability density function (pdf) with a mean $\mu_{\ln }=5.455$ and standard deviation $\sigma_{\ln }=0.925$. To visualize the inter-annual variability, the $\mathrm{CP}$ time series is also presented in Fig. 2 along with the corresponding MS record from NM in monthly mean bins. In addition distinct climate related events like strong El Niño periods in 1997 and 2006 or the Pinatubo eruption in 1991 are marked with bars. Here we consider only the period from 1989 through 2009, which is furthermore used for time series analyses. Data gaps in the period before 1989 are unbearable for this purpose. Still missing data (November and December 1989; AugustDecember 1990) were patched with long-term means of the corresponding months.

Apart from distinct inter-annual variations, the CP time series is characterized by a strong seasonality. Figure 3 shows the mean seasonality of CP concentrations for the years 1991-2009, based on daily mean values together with respective data of non-sea salt sulfate $\left(\mathrm{nss}-\mathrm{SO}_{4}^{2-}\right.$ ) as well as MS, based on weekly aerosol samples within the same period. Obviously the seasonal $\mathrm{CP}$ concentration maximum in March shows up in three stages, starting typically in September and rising again in December and February. Note that this characteristic behaviour is not an artifact of the averaging process, but could be observed more or less pronounced each year (also discernible in Figs. 1 and 2). The relative seasonal 

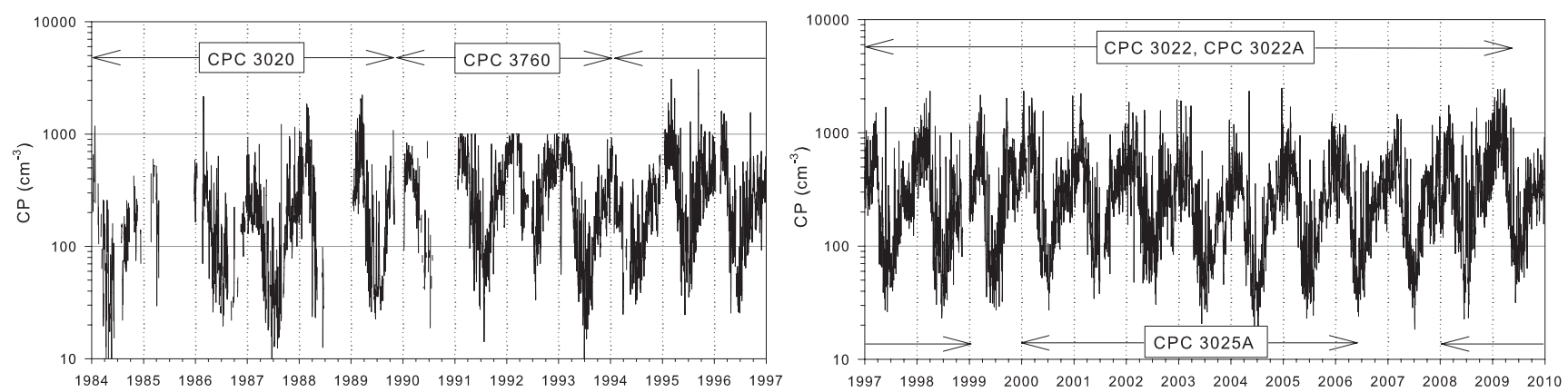

Fig. 1. Time series of the measured CP concentrations (daily means). Also indicated are the operation periods of the different particle counters types. Results from the CPC 3022/3022A are plotted throughout in the lower graph, except from April 2009 ongoing, when only a CPC 3025A was in operation. Note the different $50 \%$ cut-off diameters listed in Table 1.

amplitude, i.e. $0.5 \times\left(\mathrm{CP}_{\max }-\mathrm{CP}_{\min }\right) / \mathrm{CP}_{\text {median }}$ is 1.35 (mean absolute amplitude around $350 \mathrm{~cm}^{-3}$ ).

In order to estimate the effect of vertical mixing within the planetary boundary layer (PBL) on CP concentrations, we calculated the so-called local bulk Richardson number (Stull, 1988), because turbulence measurements are not available:

$$
R i_{\mathrm{B}}=\frac{g \Delta \theta / \Delta z}{\theta\left[\left(\frac{\Delta \boldsymbol{U}}{\Delta z}\right)^{2}+\left(\frac{\Delta \boldsymbol{V}}{\Delta z}\right)^{2}\right]}
$$

where $g$ is the gravitational constant $\left(9.81 \mathrm{~m} \mathrm{~s}^{-2}\right), z$ is the height above ground, $\theta$ is the potential temperature, $\boldsymbol{U}$ and $\boldsymbol{V}$ are the wind vectors in $\mathrm{x}$ and y direction, respectively. The gradients where approximated by simply taking the measured temperatures and wind velocities at $2 \mathrm{~m}$ and $10 \mathrm{~m}$ height. We sorted $\mathrm{CP}$ concentrations into these two cases: (1) turbulent flow, i.e. potentially well mixed PBL with $R i_{\mathrm{B}}<0.25$ and, (2) laminar flow, i.e. suppressed vertical mixing associated with temperature inversion with $R i_{\mathrm{B}}>1.0$. Like CP concentrations, the $R i_{\mathrm{B}}$ vertical mixing parameter shows a distinct seasonality with higher values (stronger inversion strength) during winter when CP levels are lowest. Hence we differentiate between summer (December through March) and winter (May through October) to avoid a seasonal bias for this analysis. During summer, mean $\mathrm{CP}$ concentrations are tentatively higher during laminar flow conditions $\left(724 \mathrm{~cm}^{-3}\right.$ for $R i_{\mathrm{B}}>1.0$ compared to $574 \mathrm{~cm}^{-3}$ for $\left.R i_{\mathrm{B}}<0.25 ; p<10^{-41}, n=35730\right)$, while during winter the result is vice versa $\left(152 \mathrm{~cm}^{-3}\right.$ for $R i_{\mathrm{B}}>1.0$ compared to $175 \mathrm{~cm}^{-3}$ for $R i_{\mathrm{B}}<0.25 ; p<10^{-22}, n=54170$ ).

In Fig. 4 the results of our TD experiments are presented as boxplots. Unfortunately only one CPC could be connected with the TD which means that aerosol volatility could not be measured simultaneously at $125^{\circ} \mathrm{C}$ and $250^{\circ} \mathrm{C}$. As a compromise we adjusted the temperature each day around 16:00 LT to $125^{\circ} \mathrm{C}$ or $250^{\circ} \mathrm{C}$, respectively. Consequently the time series for $\mathrm{CP}$ volatile at $125^{\circ} \mathrm{C}\left(\mathrm{CP}_{\mathrm{vol}} \mathrm{Eq}\right.$. 3) or non-volatile at $250^{\circ} \mathrm{C}\left(\mathrm{CP}_{\text {nonvol }}\right.$, Eq. 4$)$ is only available in a 2-days rhythm $\left(\mathrm{CP}_{\mathrm{RT}}, \mathrm{CP}_{125}\right.$, and $\mathrm{CP}_{250}$ are $\mathrm{CP}$ concentrations measured at room temperature, $125^{\circ} \mathrm{C}$ and $250^{\circ} \mathrm{C}$, respectively):

$\mathrm{CP}_{\mathrm{vol}}=\mathrm{CP}_{\mathrm{RT}}-\mathrm{CP}_{125}$

$\mathrm{CP}_{\text {nonvol }}=\mathrm{CP}_{250}$

The purpose of these experiments is to characterize particle volatility on longer (seasonal) time scales. Nevertheless, at a given temperature the TD data are available in $15 \mathrm{~min}$ averages and thus short-term variations of volatile or non-volatile (but not semi-volatile!) CP concentrations are detectable. To calculate the portion of semi-volatile particles $\left(\mathrm{CP}_{\text {semivol }}\right.$, Eq. 5), $\mathrm{CP}_{\mathrm{vol}}$ and $\mathrm{CP}_{250}$ data from different consecutive days have to be considered. We relied on the calculated mean difference using $\mathrm{CP}_{250}$ from the day before and after a given $\mathrm{CP}_{125}$ was measured:

$\mathrm{CP}_{\text {semivol }}=\mathrm{CP}_{125}-\mathrm{CP}_{250}$

Clearly, this procedure is a compromise and $\mathrm{CP}_{\text {semivol data }}$ have to be considered with caution. Obviously, the volatile and semi-volatile portion of the particles shows a summer maximum, while the non-volatile part dominates during winter (Fig. 4). Results from our scattered diffusion screen experiments indicate that the relative fraction of nonvolatile particles (i.e. most probably sea salt aerosol) with $D_{\mathrm{p}}<40 \mathrm{~nm}$ is negligible during summer (typically below $10 \%)$ but roughly $(30 \pm 20 \%)$ during winter.

As described above, from the difference of the $\mathrm{CP}$ concentrations measured by one of the CPC $3022\left(\mathrm{CP}_{7}\right)$ and the UCP $3025 \mathrm{~A}\left(\mathrm{CP}_{3}\right)$, the contribution of nucleation mode or ultrafine condensation particles between $3 \mathrm{~nm}$ and $7 \mathrm{~nm} D_{\mathrm{p}}$ $\left(\mathrm{UCP}_{3,7}\right)$ can be assessed. The raw $\mathrm{UCP}_{3,7}$ data set shows an extremely high variability on each time scale. Typically elevated $\mathrm{UCP}_{3,7}$ concentrations appear in peaks of some hours duration, which may be assigned to discrete nucleation events. Part of the variability surely comes from the 

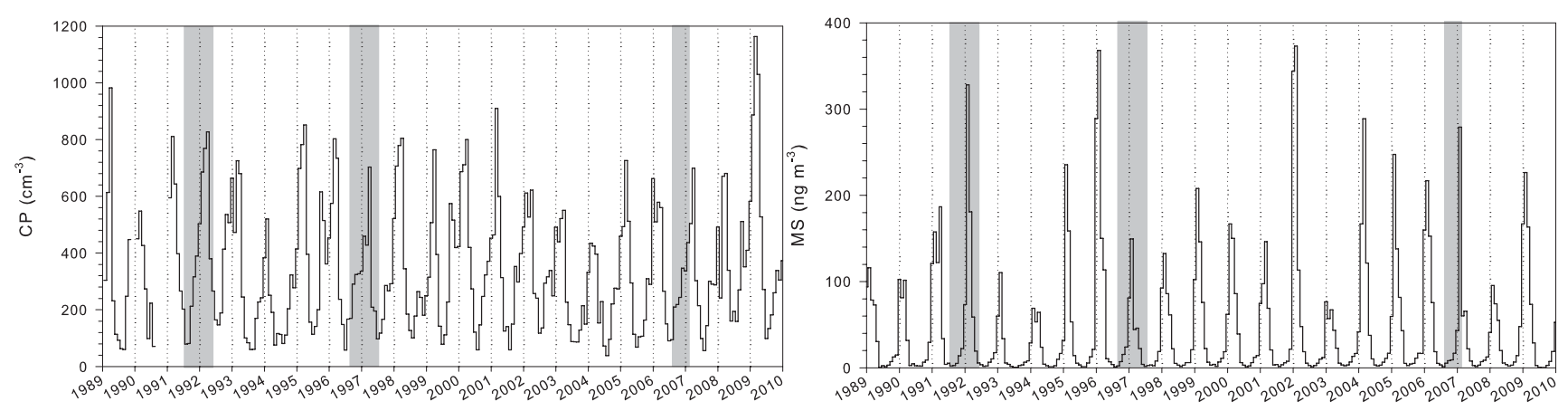

Fig. 2. Condensation particle time series (a) and methane sulfonate (MS) record from NM (b), both displayed in monthly mean bins. Shaded grey areas: El Niño events (1997 and 2006) and eruption of Mt. Pinatubo (1991).

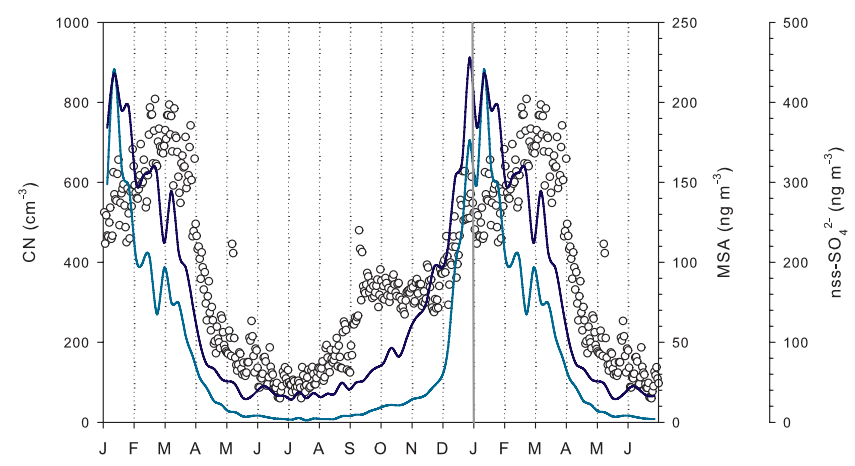

Fig. 3. Mean annual cycle of the $\mathrm{CP}$ concentrations (circles, based on daily mean values for the period 1991 through 2009), nss-SO ${ }_{4}^{2-}$ and MS (solid blue and cyan line, respectively, both based on weekly samples taken during the same period). The graph comprises 18 months starting from January to show the summer maxima without cease.

high uncertainty associated with subtracting comparable values from each other, measured by different CPCs. We assumed an independent concentration uncertainty of $\pm 10 \%$ for each CPC. In addition counting-statistics error could be significant at very low concentrations. Consequently, for typical cases, when $\mathrm{UCP}_{3,7}$ concentrations are in the range of $>100 \mathrm{~cm}^{-3}$, the uncertainty is lower than $\pm 30 \%$, increasing to roughly $\pm 70 \%$ around $50 \mathrm{~cm}^{-3}$, while below say $10 \mathrm{~cm}^{-3}$ the difference between both instruments emerged usually as insignificant. Furthermore, in order to preclude spurious $\mathrm{UCP}_{3,7}$ concentrations we applied a simple but conservative threshold for valid $\mathrm{UCP}_{3,7}$ concentrations: We only accept $\mathrm{UCP}_{3,7}$ values above the total sum error of each CPC signal, i.e. $\mathrm{UCP}_{3,7}>0.1 \times \mathrm{CP}_{3}+0.1 \times \mathrm{CP}_{7}$.

The results of the corresponding hourly means are presented in Fig. 5. Apart from remarkable day to day and also inter-annual variability, we found a distinct mean seasonality summarized in Fig. 6. $\mathrm{UCP}_{3,7}$ concentrations sporadically measured during June and July, though significant according to our threshold criterion, are disputable. During these
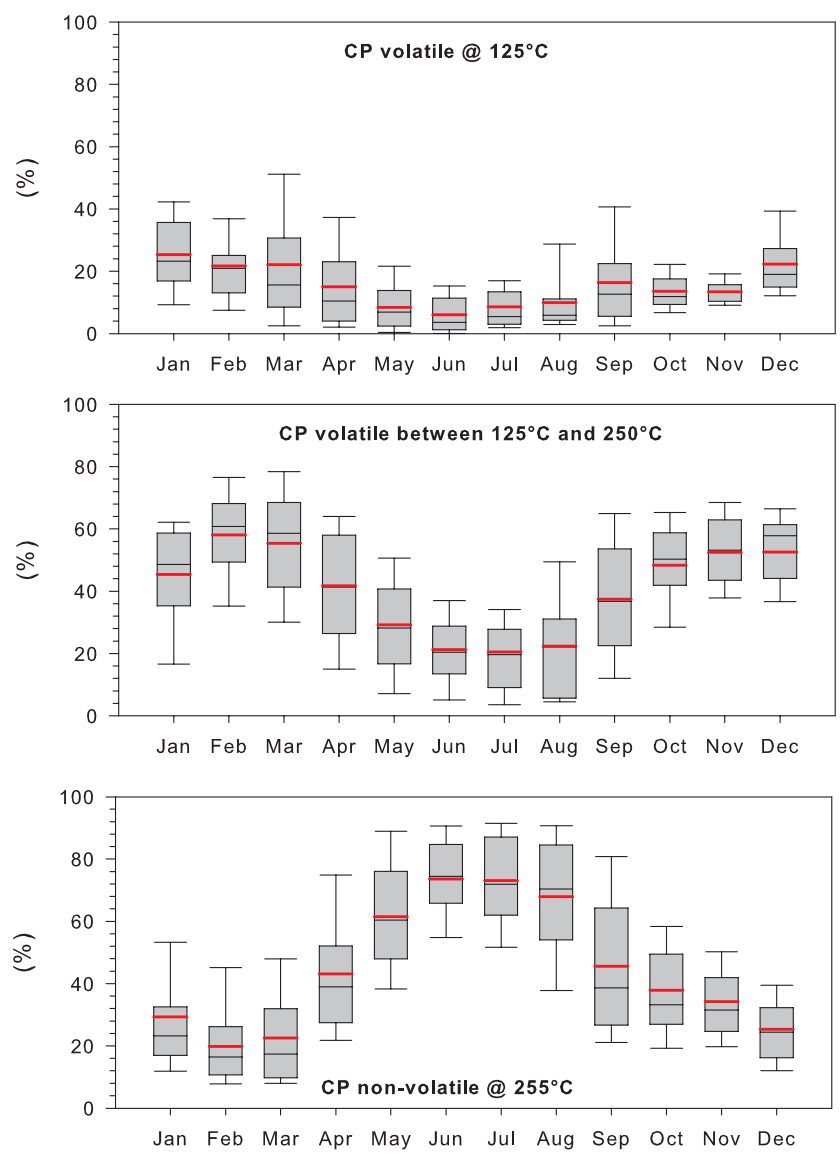

Fig. 4. Box plots of the mean seasonality of the volatile, semivolatile and refractory portion of the measured particle concentrations for the years 2005-2007. Lines in the middle of the boxes represent sample medians (mean: red line), lower and upper lines of the boxes are the 25 th and 75 th percentiles, and whiskers indicate the 10th and 90th percentiles.

months, $\mathrm{UCP}_{3,7}$ concentrations were actually around zero for most of the time, but sporadically showed peak values up to some tens $\mathrm{cm}^{-3}$. Although all relevant data were measured 
under clean air conditions as defined above, especially during calm weather periods, even under non-critical wind conditions, the impact of exhaust fumes from station operation could not entirely be ruled out.

\section{Discussion}

\subsection{Long term trend and inter-annual variability}

\subsubsection{Long term trend}

The reliability of a long term trend, derived from a measured time series depends critically on the consistency and homogeneity of the experimental conditions. In consideration of this fact and as mentioned above, we note that our CP observations before 1989 comprised severe data gaps, especially during the summer months when the seasonal $\mathrm{CP}$ maximum appeared. Thus we decided to exclude this period from trend analyses. Another point to bear in mind is the higher $D_{\mathrm{p}(50 \%)}$ of the CPC 3020 in operation before 1990 and exclusive use of an UCPC 3025A with lower $D_{\mathrm{p}(50 \%)}$ from February 2009 through February 2010. Apart from this, in 1991, 1995 and in 2009 renewed observatories were relocated each with about $6 \mathrm{~km}$ south compared to the corresponding previous locations due to initial operations of new main stations (NM-II and NM-III). We realized that these movements did not have any obvious impact on our aerosol records (see also Weller et al., 2011).

Trend analyses by the Mann-Kendall test with Sen's slope estimate applied to the CP time series, their respecting logarithmic as well as their anomaly representations did not show any statistically significant trend, neither for the period 1989 through 2010, nor for the sub-sample from July 1990 to February 2009 (omitting periods when CPCs were operative with different $\left.D_{\mathrm{p}(50 \%)}\right)$. Furthermore we performed the same analyses separately for each month to examine if there was any trend in the seasonality during our observation period. Again we could not substantiate any significant trend ( $p>0.1$ throughout). Mean, median, and geometric mean $\mathrm{CP}$ concentrations for the whole observation period at $\mathrm{NM}$ are $343 \mathrm{~cm}^{-3}, 258 \mathrm{~cm}^{-3}$, and $232 \mathrm{~cm}^{-3}$, respectively. In contrast, Jaenicke et al. (1992) reported an increasing unexplained trend of $9.63 \%$ per year for the period between 1982 and 1990, but this trend appears questionable if the fragmentary record before 1986 is ignored (Fig. 1 and see also Fig. 1 in Jaenicke et al., 1992).

The sole comparable long-term CP record from Antarctica was obtained at Amundsen-Scott Base (South Pole). In agreement with our results, no trend could be substantiated, at least for the period from 1974 through 1994 (Robinson et al., 1988; Bodhaine, 1996). In contrast, during the nine-year period from 1977-1985, Samson et al. (1990) found a significant decrease of CP concentrations at South Pole and speculated about changes in the Ross-Amundsen-Bellinghausen

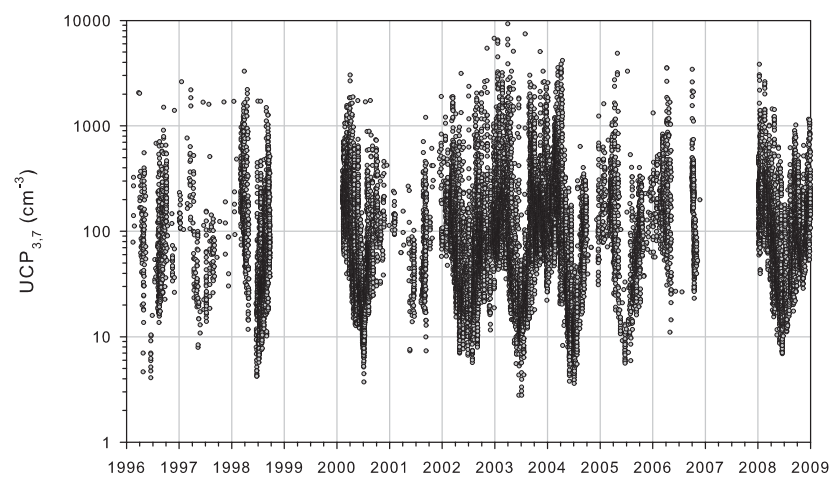

Fig. 5. Measured concentrations of ultrafine particles, $\mathrm{UCP}_{3,7}\left(D_{\mathrm{p}}\right.$ between $3 \mathrm{~nm}$ and $7 \mathrm{~nm}$ ) based on hourly means. Note that the larger data gaps from late 1998 until early 2000 and fall 2006 through 2007 were caused by malfunction of the UCP 3025 A.

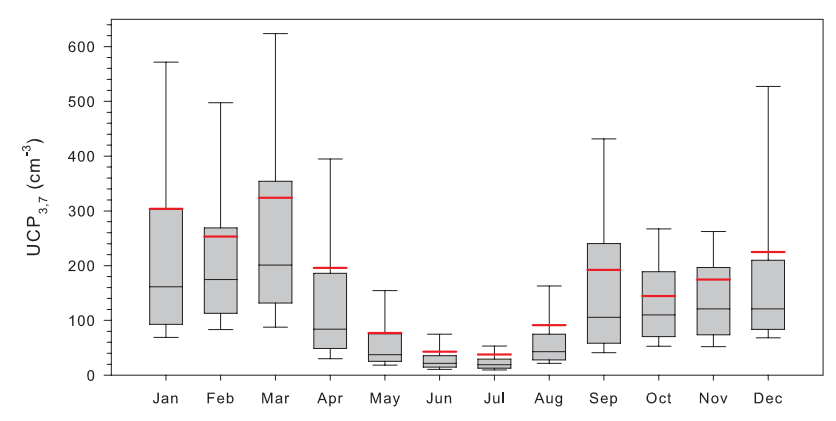

Fig. 6. Notched box plots of the mean seasonality of $\mathrm{UCP}_{3,7}$ concentrations. For description of the symbols see Fig. 4.

sea sector or changing transport processes from this region to South Pole having caused this trend. Typical CP concentrations observed at South Pole were lower by a factor of around two compared to coastal NM, reflecting less efficient transport of the largely marine biogenic CP source (photo-oxidation of algae derived precursor dimethylsulfide, DMS, to nss- $\mathrm{SO}_{4}^{2-}$ and MS aerosol; see discussion below) to the Antarctic Plateau. Year-round observation available from Antarctic coastal sites Mawson $\left(67^{\circ} 36^{\prime} \mathrm{S}, 62^{\circ} 53^{\prime} \mathrm{E}\right)$ and Syowa $\left(69^{\circ} 00^{\prime} \mathrm{S}, 39^{\circ} 35^{\prime} \mathrm{E}\right)$, showed CP concentrations comparable to NM (Gras, 1993; Ito, 1985; Hara et al., 2011a). Note that due to exceedingly strong and perpetual katabatic winds and low sea salt aerosol concentrations, Mawson has a somewhat continental character (Gras, 1993) which seems, however, not to be reflected in CP concentrations typically observed at this site. Finally, base line sector CP measurements performed at Cape Grim, Tasmania $\left(40^{\circ} 42^{\prime} \mathrm{S}, 144^{\circ} 42^{\prime} \mathrm{E}\right)$ during the years $1977-1992$ indicated annual median values between 250 and $280 \mathrm{~cm}^{-3}$ to be typical for the Southern Ocean (Gras, 1990, 1995). 


\subsubsection{Inter annual variability and impact of distinctive events}

From Fig. 2 it is evident that none of the strong El Niño events consistently influenced the measured $\mathrm{CP}$ concentrations. Although so far not explicitly discussed by Bodhaine (1996), this seems also to be valid for the South Pole record for the period 1974-1994 (Bodhaine, 1996; Fig. 3 therein). In contrast, Gras (1990) found a distinct negative correlation between $\mathrm{CP}$ concentrations observed at Cape Grim with the SOI. The Pinatubo eruption was the strongest volcanic event in the antecedent century (June 1991 at $15^{\circ} \mathrm{N}$ ) and injected around $18 \pm 2 \mathrm{Mt}\left(10^{12} \mathrm{~g}\right) \mathrm{SO}_{2}$ up to the middle stratosphere (Krueger et al., 1995) causing a historical disturbance of the stratospheric sulfate layer (e.g. Russell et al., 1996) associated with an appreciable impact on global climate (McCormick et al., 1995). This event was followed by the much smaller eruption of Cerro Hudson $\left(45^{\circ} \mathrm{S}\right)$ in October 1991. Legrand and Wagenbach (1998) extensively discussed the impact of both eruptions and concluded that this event lead only to a relatively small perturbation of the near surface nss-SO ${ }_{4}^{2-}$ level at NM. Particle concentrations at NM appeared not significantly higher during austral summer 1991/1992, when the impact of volcanogenic sulfate aerosol should have been most pronounced (Russel et al., 1996; Legrand and Wagenbach, 1998). Consequently the overall relevance of the stratosphere as particle source for coastal boundary layer air at NM seems negligible and also nss- $\mathrm{SO}_{4}^{2-}$ measurements indicated an only ancillary contribution (Minikin et al., 1998; Legrand and Wagenbach, 1998).

For further time series analyses in the time and spectral (frequency) domain, it was important to avoid any spurious influence of the inherent seasonality of the CP data set. Hence, we consider now the anomalies derived from the CP and the SIE records (note that SAM and SOI are anomalies by definition). Generally no significant correlation with circulation indices or SIE could be detected in the time domain. Furthermore, the CP record does not show any significant periodicities $>1 \mathrm{yr}$. Only a MC-SSA data adaptive filtered representation (i.e. a reconstruction based on the leading four principal components, explaining $35 \%$ of the $\mathrm{CP}$ variability) revealed a broadband, i.e. non-harmonic periodicity between 2 and $3 \mathrm{yr}$, which is also evident in the SAM and SOI records. Nevertheless, there is definitely no significant cross correlation between CP anomalies and SAM or SOI, neither in the time nor in the frequency domain. In conclusion, statistical time series analyses revealed that though CP concentrations at NM exhibit a pronounced inter-annual variability, long term trends and correlations with the climate related indices SIE, SAM, and SOI are virtually absent.

In summary, our conclusions drawn from $\mathrm{CP}$ time series analyses appear consistent with recent findings regarding the long-term record of the ionic aerosol composition at NM (Weller et al., 2011). The main sources of Antarctica aerosol, as there are biogenic sulfur (i.e. nss- $\mathrm{SO}_{4}^{2-}$ and MS) and sea salt compounds, seem to be essentially dependent on the patchy oceanic source distribution and transport efficiency, the latter governed by regional or even local meteorology, while correlations with climate related indices show weak, mostly inconsistent and barely meaningful correlations (Weller et al., 2011) indicating a minor relevance of these couplings for the observation period and site under discussion.

\subsubsection{Impact of PBL inversion strength}

During winter regional DMS sources can be considered as inactive due to sea ice coverage and lack of actinic radiation. In this case, tentatively higher CP concentrations are observed when the PBL showed and turbulent flow $\left(R i_{\mathrm{B}}<0.25\right)$. Such a situation is characteristic for stormy weather under passing low pressure systems which potentially boosts sea salt production but also facilitates long-range transport and downmixing of free tropospheric air masses (König-Langlo et al., 1998; Hara et al., 2011a). During summer, strong surface inversions and laminar flow are typically associated with bright weather conditions and potentially higher photochemical activity. Now particle concentrations seem to be dominated by regional sulfur aerosol sources and photochemical induced particle nucleation (see Sect. 4.3). In summary, we cannot clearly separate the effect of boundary layer stability on particle concentrations from factors like long range transport and photo-chemistry. Hence, the influence of vertical mixing appeared equivocal.

\subsection{Link to chemical composition and seasonality}

\subsubsection{Survey of the chemical composition of coastal Antarctic aerosol}

From previous investigations we know that the ionic composition of the aerosol at NM shows a distinct seasonality with high portion of biogenic sulfur during summer (about $36 \%$ by weight referring to ionic species and mineral dust from November through March), decreasing to less than $7 \%$ from April through October while throughout the year sea salt aerosol is clearly dominating with a relative portion of around $50 \%$ during summer increasing to $86 \%$ in winter (Weller et al., 2008). Nevertheless, due to high variability of the ionic aerosol composition, biogenic sulfur frequently constitutes the main ionic aerosol compound (more than $75 \%$ ) during summer, while during winter sea spray generally dominates (Weller and Lampert, 2008). Due to the lack of size-segregated aerosol chemistry investigations at Neumayer, we refer to respective measurements from the Finnish station Aboa $\left(73^{\circ} 03^{\prime} \mathrm{S}, 13^{\circ} 25^{\prime} \mathrm{W}\right)$ and the French station Dumont d'Urville $\left(66^{\circ} 40^{\prime} \mathrm{S}, 104^{\circ} 01^{\prime} \mathrm{E}\right)$ showing a similar mass size distribution for nss- $\mathrm{SO}_{4}^{2-}$, MS and $\mathrm{NH}_{4}^{+}$with a dominant mode in the accumulation size range at about $0.3 \mu \mathrm{m}$, 
while sea salt and nitrate were nearly exclusively in the super micron size range (Teinilä et al., 2000; Jourdain and Legrand, 2001).

\subsubsection{Link to chemical composition by TD experiments}

Coinciding nss- $\mathrm{SO}_{4}^{2-}$, MS and $\mathrm{CP}$ concentration maxima in summer (Fig. 3), indicate the dominance of biogenic sulfur aerosol in determining particle concentration. This conclusion is consistent with highest non-volatile particles portions during winter, while volatile and semi-volatile particles dominate during summer (Fig. 4). For the years 2005 and 2006 ionic composition of the aerosol is available in daily resolution and could be compared with the TD experiments. The accordant results presented in Fig. 7 demonstrate the coherence of biogenic sulfur aerosol with volatile and semi-volatile particles and sea salt with the refractory (nonvolatile) portion. This agreement is of course only qualitative, because TD experiments refer to particle number concentrations while the chemical composition corresponds to particle mass concentration. Even during summer, when particles are mainly volatile or semi-volatile, aerosol mass can frequently be dominated by (coarse mode) sea salt particles. During winter the situation is more uniform: TD results reveal that roughly $80 \%$ of the particles are refractory suggesting that particle number concentrations and aerosol mass are dominated by sea salt aerosol (Figs. 4 and 7). Nevertheless, non-sea-salt sub-micrometer aerosol (i.e. volatile or semi volatile sulfate and nitrate, as well as non-volatile mineral dust and black carbon), though negligible by mass, may partly contribute to the observed winter-time $\mathrm{CP}$ concentrations.

A more detailed inspection of this overall consistent picture revealed some open questions, especially associated with the portion of semi-volatile particles. Measured $\mathrm{NH}_{4}^{+}$ concentrations at $\mathrm{NM}$ are so low that in general only roughly $15 \%, 10 \%$, or $7.5 \%$ of the nss- $\mathrm{SO}_{4}^{2-}$ could potentially be bound as $\mathrm{NH}_{4} \mathrm{HSO}_{4}$ (ammoniumbisulfate), $\left(\mathrm{NH}_{4}\right)_{3} \mathrm{H}\left(\mathrm{SO}_{4}\right)_{2}$ (letovicite), or $\left(\mathrm{NH}_{4}\right)_{2} \mathrm{SO}_{4}$ (ammoniumsulfate), respectively, the most plausible candidates for semi-volatile particles. This has to be compared with the TD results which revealed that about $50 \%$ of the particles are semi-volatile and $25 \%$ volatile. Note, although determination of the semivolatile part was inherently inaccurate, this caveat could hardly have biased the results all up to the higher end. Thus particle number concentrations seem to be dominated by semi-volatile particles, necessitating a smaller mean diameter compared to the volatile portion to be in agreement with the chemical composition, which is hardly plausible. We may speculate that biogenic sulfur aerosol at NM is to a lesser extent a heterogeneous mixture of $\mathrm{H}_{2} \mathrm{SO}_{4}$ (volatile) and $\mathrm{NH}_{4} \mathrm{HSO}_{4}$ (semi-volatile) particles, but rather an internal mixture of partly neutralized sulfuric acid like $\mathrm{H}_{2} \mathrm{O}$ $\left(\mathrm{NH}_{4}\right) \mathrm{HSO}_{4}-\mathrm{H}_{2} \mathrm{SO}_{4}$ (including most probably methane sulfonic acid). This is supported by particle volatility measure-
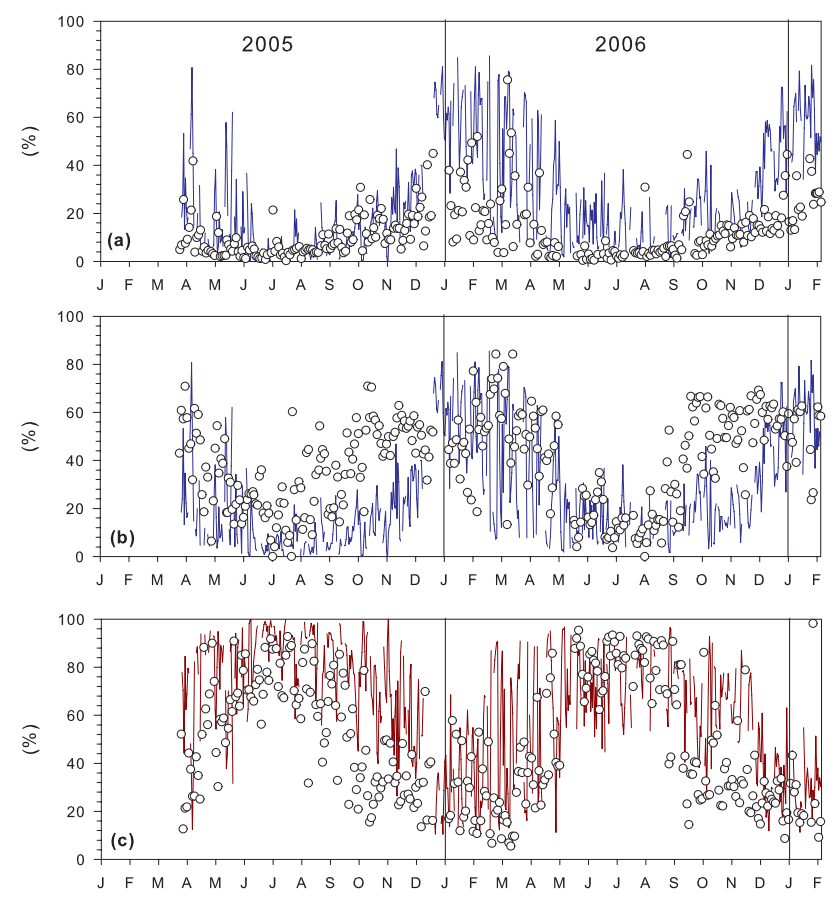

Fig. 7. Results of the thermodenuder experiments: portion of volatile (a) and semi-volatile (b) particles based on daily mean values along with the portion of biogenic sulfur (i.e. the sum of nss$\mathrm{SO}_{4}^{2-}$ and MS concentrations, blue line) as well as refractory particles (c) along with the portion of sea salt aerosol (red line). The ionic concentrations were derived from daily aerosol samples taken during the same period.

ments at the Finnish Antarctic Station Aboa (Asmi et al., 2010), Syowa (Hara et al., 2011b), and results from combined FTIR spectrometer and sun photometer measurements at NM in January/February 2000 (Rathke et al., 2002). The stoichiometric composition and hence the volatility threshold temperature of this internally mixed aerosol should be variable depending on prevailing atmospheric chemistry of DMS oxidation (gas phase or in cloud processes, presence of $\mathrm{NH}_{3}$ ) and meteorological conditions. An open question is the contribution of organic carbon in particles. Measurements of hygroscopicity, volatility and chemical composition of aerosol particles at the Finnish Antarctic station Aboa indicate an organic fraction of around $20-30 \%$ in the $<1 \mu \mathrm{m}$ aerosol mass (Asmi et al., 2010).

\subsubsection{Seasonality}

Obviously the shape of the CP seasonality with its characteristic stepwise increase in spring is different to the distinct and mostly concurrent seasonal maxima of nss- $\mathrm{SO}_{4}^{2-}$ and MS (Fig. 3) in January. It seems that especially the portion of semi-volatile particles increased during early spring, while the increase of the volatile fraction is more gradually (Figs. 4 and 7). In particular for the early $\mathrm{CP}$ rise in 
September there is no equivalent in the $\mathrm{nss}^{-\mathrm{SO}_{4}^{2-}}$ and MS seasonality and the absolute $\mathrm{CP}$ maximum in March is accompanied by an only much weaker nss- $\mathrm{SO}_{4}^{2-}$ and MS secondary maximum (Fig. 3). A plausible explanation for this finding could be new particle formation (see next section). This photo-chemically initiated process primarily enhanced particle number concentrations (mainly within the nucleation and Aitken modes) but hardly aerosol mass and hence nss$\mathrm{SO}_{4}^{2-}$ and $\mathrm{MS}$ concentrations. Indeed, the observed seasonality of $\mathrm{UCP}_{3,7}$ concentrations supports this perception (Fig. 6). The maximum of $\mathrm{UCP}_{3,7}$ (and $\mathrm{CP}$ ) concentrations in March may be initiated by enhanced bio-productivity associated with the regular retreat of the last sea ice in the nearby Atka Bay (about $8 \mathrm{~km}$ northeast of the station) in late February/March. However, considering the short atmospheric lifetime of nucleation mode particles (coagulation lifetime in remote marine areas according to Heintzenberg et al. (2004) roughly $10 \mathrm{~h}$ at $3 \mathrm{~nm} D_{\mathrm{p}}$ ), observed nucleation during September is difficult to interpret because SIE is at maximum then and only sporadic polynias appear in the adjacencies of NM. One may speculate about the role of springtime photochemical processes associated with halogen activation over sea ice pertaining to DMS oxidation and aerosol formation (e.g. von Glasow and Crutzen, 2004; Simpson et al., 2007; Read et al., 2008). An inspection of our surface ozone time series revealed that several tropospheric ozone depletion events (indicating the impact of halogen chemistry) were accompanied by enhanced CP concentrations, but this finding is not consistent throughout. Nevertheless, supporting our hypothesis, year-round long-pass DOAS at Halley showed maximum boundary layer $\mathrm{BrO}$ and $\mathrm{IO}$ concentration during spring (Saiz-Lopez et al., 2007).

Similar to NM, CP concentrations at South Pole steadily increase in September to a distinct November peak. In contrast to NM there is a characteristic December subminimum, usually followed by short periods with increased CP concentrations from the second half of January through March (Samson et al., 1990; Figs. 1 and 2 therein). Note that South Pole is the sole continental Antarctic site discussed here, i.e. marine aerosol sources are absent and local sulfur aerosol formation seems negligible as demonstrated by the recent ISCAT campaign (Mauldin III et al., 2004). Consequently, CP concentrations at South Pole are governed by atmospheric transport processes (Samson et al., 1990; Mauldin III et al., 2004)

Mean annual cycles derived from about two years of continuous CP observations at Mawson and Syowa showed enhanced concentrations between September and April (Gras, 1993; Ito, 1985; Hara et al., 2011a), but only at Syowa a distinct absolute maximum in February/March, analogue to NM, was identifiable (Ito, 1985). Regarding the temperate zone of the Southern Ocean, a comparison with CP observations from Cape Grim revealed once again a broad maximum between September and April (Gras, 1990), reflecting the annual cycle of biological activity in the surface water of the
Southern Ocean. Finally a recent model approach predicted a broad CP maximum between November and March for NM, but could neither reproduce the early increase in September nor the absolute maximum in March (Spracklen et al., 2010; Fig. 5 therein). This discrepancy indicates that more regional or even local processes not resolved in the present model play a decisive role in determining particle concentrations at this site.

\subsection{Diurnal cycle of $\mathrm{CP}$ and ultrafine particle concentrations}

From September through April, $\mathrm{UCP}_{3,7}$ values commonly showed peaks with a typical duration of $2-10 \mathrm{~h}$, frequently on top of a persistent background $\mathrm{UCP}_{3,7}$ level of several tens per $\mathrm{cm}^{3}$. Such peaks potentially indicate nucleation events. Note, however, that according to Dal Maso et al. (2005) a particle formation or nucleation event is only existent if a distinct nucleation mode appears that shows signs of growth. Unfortunately, the latter could not be assessed by our experimental equipment. Figure 8 is a representative observed at 12 February 2006. The temporal resolution of the measured CP concentrations was $150 \mathrm{~s}$ and error bars indicate the estimated accuracy of the derived $\mathrm{UCP}_{3,7}$ concentrations. The arrow marks the moment when the diffusion screen was switched on. During these 15 min, $\mathrm{UCP}_{3,7}$ concentrations decayed to negligible amounts and the estimated abundance of particles below the diffusion screen cut-off of $40 \mathrm{~nm} \mathrm{D}_{p}$ was around $65 \%$. $\mathrm{UCP}_{3,7}$ concentration showed a diurnal cycle with highest values primarily during afternoon. Figure 9 presents the mean diurnal concentration cycle for all valid $\mathrm{UCP}_{3,7}$ values (note that during winter $\mathrm{UCP}_{3,7}$ concentrations are generally negligible). A comparable diurnal cycle, which is evident for the months September through April but absent from May through August was also found for $\mathrm{CP}_{7}$ concentrations (not shown). Concurrent results from the TD experiments, which were restricted to $\mathrm{CP}_{7}$ concentrations (and not $\mathrm{UCP}_{3,7}$ ) indicate a highly variable contribution of volatile and semi-volatile particles (ranging between $20 \%$ and $78 \%$ for each class), while the portion of non-volatile aerosol was generally below $20 \%$ during high $\mathrm{UCP}_{3,7}$ events.

In agreement with previous results from the Finnish Antarctic Station Aboa (Koponen et al., 2003), $\mathrm{UCP}_{3,7}$ concentration peaks of several hundred $\mathrm{cm}^{-3}$ were quite frequent at $\mathrm{NM}$, but did very rarely exceed $1000 \mathrm{~cm}^{-3}$. As expected, natural nucleation events could not be detected at continental South Pole (Park et al., 2004). For comparison, much higher $\mathrm{UCP}_{3,7}$ concentrations $\left(>10^{4} \mathrm{~cm}^{-3}\right)$ were typically observed e.g. during nucleation events in mid-latitude boreal forests (Kulmala et al., 2001) or certain coastal regions with extensive exposed shorelines during low tide (O'Dowd et al., 2002a; McFiggans et al., 2010). We estimated from the ascent branch of the observed $\mathrm{UCP}_{3,7}$ concentrations $\left(\mathrm{N}_{3,7}\right)$ in Fig. 8 a nucleation rate $\Delta \mathrm{N}_{3,7} / \Delta t$ of 


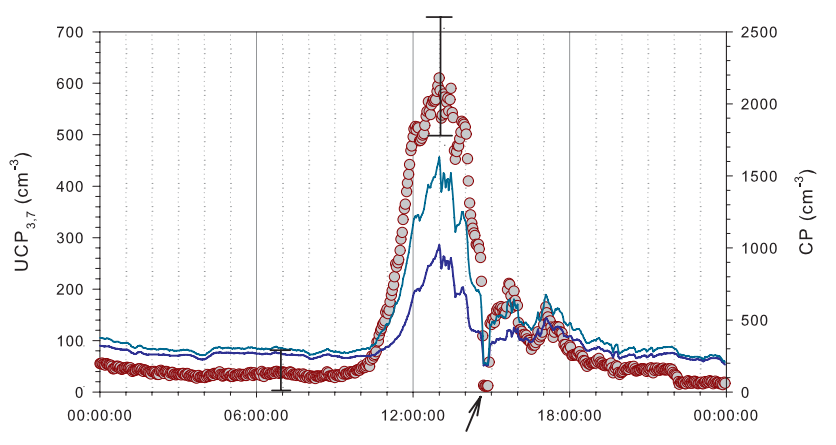

Fig. 8. $\mathrm{UCP}_{3,7}$ concentrations observed at 12 February 2006 (circles, left hand scale) derived from the CPC 3022A and UCPC 3025A instruments (green and blue line, respectively; right hand scale) in the highest available temporal resolution (150 s). The two error bars visualize the typical uncertainty of the calculated $\mathrm{UCP}_{3,7}$ concentrations (see main text). The arrow marks the moment when the diffusion screen was switch on for $15 \mathrm{~min}$.

about $0.05-0.07 \mathrm{~cm}^{-3} \mathrm{~s}^{-1}$, a value which could be somewhat biased by advection of unknown spatial $\mathrm{UCP}_{3,7}$ concentration variations (the wind speed was around $8 \mathrm{~m} \mathrm{~s}^{-1}$ ). According to Kulmala et al. (2004) this simple approach, neglecting coagulation and condensation sinks as well as transport processes, is usually reliable for clean, homogenous air masses. A comparison with other studies emerged partly difficult, because different experimental and evaluation methods were employed to determine nucleation rates. Usually, previous investigations refer to particles within 3-10 nm $D_{\mathrm{p}}$, often and ideally recorded by continuous size distribution measurements (see Kulmala et al., 2004 for a detailed review). Typically new particle formation rates in the range of $0.01-10 \mathrm{~cm}^{-3} \mathrm{~s}^{-1}$ were characteristic for remote boundary layer air, reaching in extreme cases (coastal areas and industrial plumes) occasionally $10^{4}-10^{5} \mathrm{~cm}^{-3} \mathrm{~s}^{-1}$ (Kulmala et al., 2004). Finally these reported values as well as our estimate cannot be treated as a true nucleation rate. An assessment of the latter would require the determination of so-called thermodynamically stable cluster (TSC) concentrations in the size range $<2 \mathrm{~nm}$, which has been successfully realized only recently (Kulmala et al., 2007) or would need a considerable additional correction (Kerminen and Kulmala, 2002) which was not feasible on the base of our data. Nevertheless, we may state that nucleation rates observed at NM were rather at the lower end compared to nucleation events typically observed in continental and coastal mid-latitudes.

Considering the importance of biogenic sulfur aerosol and the presence of ammonia during summer at $\mathrm{NM}$ (Weller and Lampert, 2008), we suggest that ternary nucleation of $\mathrm{H}_{2} \mathrm{SO}_{4}$ (Kulmala et al., 2000; Sipilä et al., 2010) was the most important nucleation mechanism, probably supported by iodine compounds (O'Dowd et al., 2002a, b; McFiggans et al., 2010). As for the latter, continuous year-round DOAS measurements at NM (Frieß et al., 2001) and Halley (Saiz-

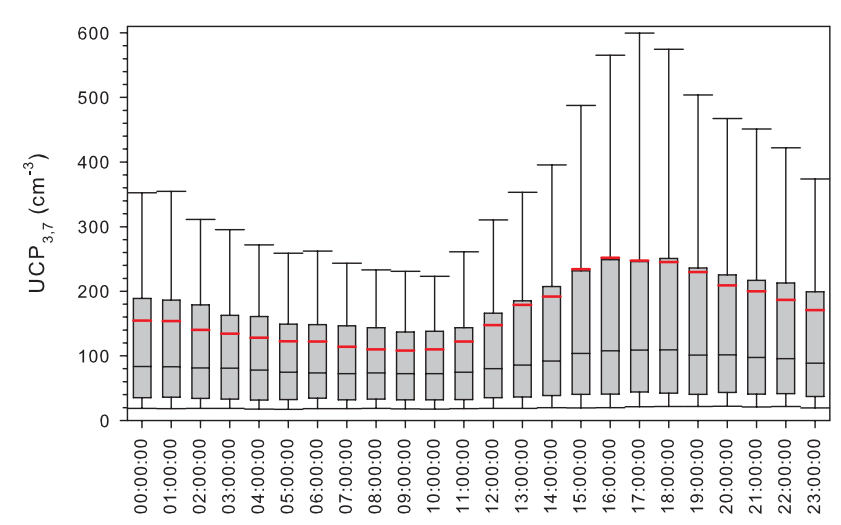

Fig. 9. Mean diurnal cycle of the $\mathrm{UCP}_{3,7}$ concentrations. For description of the symbols see Fig. 4.

Lopez et al., 2007) indicated boundary layer mixing ratios of IO comparable to results from Roscoff (Brittany), a site where iodine induced nucleation events are typical (McFiggans et al., 2010). In addition, as suggested by Asmi et al. (2010), organic compounds participate in new particle formation and particle growth process. We could not ascertain the impact from down mixing of free tropospheric air, but the observed diurnal cycle is consistent with a photochemical induced process. Nucleation events observed at NM were not associated with peculiar general weather situations, the origin of air masses (classification in marine and continental by 5-days backward trajectories), or wind velocity (note however, that at wind speeds $>10 \mathrm{~m} \mathrm{~s}^{-1} \mathrm{UCP}_{3,7}$ concentrations above $200 \mathrm{~cm}^{-3}$ were rare). Asmi et al. (2010) found some nucleation events linked with high wind speed at Aboa which they attributed to ion production by fast moving ice and snow crystals and subsequent ion-mediated nucleation (Virkkula et al., 2007). Previous results from this site reported by Koponen et al. (2003) indicated new particle formation exclusively in marine/coastal air masses in contrast to our and more recent investigations reported by Asmi et al. (2010).

\section{Conclusions}

Apart from distinct inter-annual variability, condensation particle concentrations at Neumayer showed no obvious long-term trend. This is remarkable since Antarctica experienced significant climate relevant changes in the past three decades like the development of the ozone hole (Solomon, 1999; Thompson and Solomon, 2002) or warming of the Antarctic Peninsula (Steig et al., 2009). This goes along with a consistent lack of any meaningful correlation with climate factors like sea ice extent or atmospheric circulation indices in our $25 \mathrm{yr}$ long time series of the ionic composition of the aerosol (Weller et al., 2011). In addition, an impact of outstanding events like the Mt. Pinatubo eruption and strong El Niño phases on particle concentrations 
at Neumayer was not apparent. Particle concentrations at a given site are not only determined by source strength (in our case the bio-productivity of the South Atlantic and wind induced sea salt generation) and transport efficiency governed by regional or even local meteorology, but also by the amount of pre-existing aerosol surface area acting as condensation sink (Heintzenberg et al., 2004). The latter critically affects the relevance of new particle formation and thus ultimately the particle number concentration. We infer from our examinations that eventually these processes determined most probably $\mathrm{CP}$ concentration variability at all time scales considered and obliterated the imprint of superordinate climate signals in the Southern Ocean and Antarctic region. Regarding the seasonality of particle concentrations at NM, the stepwise increase to the annual maximum in March is noticeable and evident each year but not identically seen in biogenic sulfur records. Year-round ultrafine particle detection identified particle nucleation as a plausible candidate responsible for the overall seasonality of CP concentrations. These observations emphasize the importance of local particle nucleation within the planetary boundary layer and/or down-mixing of nucleation particle rich air masses from the free troposphere governing the aerosol budget in terms of number concentration at this site.

More detailed conclusions addressing nucleation processes as well as chemical composition and growth dynamics of different particle size modes along with their seasonal and inter-annual variations require additional continuous longterm configured particle size distribution measurements and size segregated aerosol sampling. Moreover, there is still a notorious and serious lack of data regarding the vertical distribution of particles in connection with the general weather situation as well as the dynamics of their vertical exchange in South Polar regions. Future investigations should as well focus on the evaluation of congruent observations at coastal and continental Antarctic sites especially in terms of organic compounds with the objective to gain a more comprehensive picture of Antarctic aerosol dynamics.

Acknowledgements. The authors would like to thank the many technicians and scientists of the Neumayer overwintering crews, which outstanding commitment enabled achieving continuous, high quality aerosol records since 1982. We also acknowledge partly funding the initial phase of the air chemical NM Observatory programme by the German Science Foundation as well as financial support obtained within the European Community STEP program within the project Polar Atmospheric Chemistry.

Edited by: N. Riemer

\section{References}

Agarwal, J. K. and Sem, G. J.: Continuous flow, single-particlecounting condensation nucleus counter, J. Aerosol Sci., 11, 343357, 1980.

Asmi, E., Frey, A., Virkkula, A., Ehn, M., Manninen, H. E., Timonen, H., Tolonen-Kivimäki, O., Aurela, M., Hillamo, R., and Kulmala, M.: Hygroscopicity and chemical composition of Antarctic sub-micrometre aerosol particles and observations of new particle formation, Atmos. Chem. Phys., 10, 4253-4271, doi:10.5194/acp-10-4253-2010, 2010.

Bodhaine, B. A.: Central Antarctica: Atmospheric chemical composition and atmospheric transport, in: Chemical Exchange between the Atmosphere and polar snow, edited by: Wolff, E. W. and Bales, R. C., NATO ASI Series, Springer-Verlag Berlin Heidelberg, Vol. 43, 145-172, 1996.

Burtscher, H., Baltensperger, U., Budowiecki, N., Cohn, P., Hüglin, C., Mohr, M., Matter, U., Nyeki, S., Schmatloch, V., Streit, N., Weingartner, E.: Separation of volatile and non-volatile aerosol fractions by thermodesorption: instrumental development and applications, Aerosol Sci., 32, 427-442, 2001.

Capaldo, K. P., Kasibhatla, P., Pandis, S. N.: Is aerosol production within the remote marine boundary layer sufficient to maintain observed concentrations?, J. Geophys. Res., 104, 3483-3500, 1999.

Clarke, A. D., Davis, D., Kapustin, V. N., Eisele, F., Chen, G., Paluch, I., Lenschow, D., Bandy, A. R., Thornton, D., Moore, K., Mauldin, L., Tanner, D., Litchy, M., Carroll, M. A., Collins, J., and Albercook, G.: Particle Nucleation in the Tropical Boundary Layer and Its Coupling to Marine Sulfur Sources, Science, 282, 89-92, 1998.

Covert, D. S., Kapustin, V. N., Bates, T. S., and Quinn, P. K.: Physical properties of marine boundary layer aerosol particles of the mid-Pacific in relation to sources and meteorological transport, J. Geophys. Res., 101, 6919-6930, 1996.

Dal Maso, M., Kulmala, M., Riipinen, I., Wagner, R., Hussein, T., Aalto, P. P., and Lehtinen, E. J.: Formation and growth of fresh atmospheric aerosols: eight years of aerosol size distribution data from SMEAR II, Hyytiälä, Finland, Boreal Env. Res., 10, $323-$ 336, 2005.

Davison, B., Hewitt, C. N., O’Dowd, C. D., Lowe, J. A., Smith, M. H., Schwikowski, M., Baltensperger, U., and Harrison, R. M.: Dimethyl sulfide, methane sulfonic acid and physiochemical aerosol properties in Atlantic air from the United Kingdom to Halley Bay, J. Geophys. Res., 101, 22855-22867, 1996.

Feldpausch, P., Fiebig, M., Fritzsche, L., and Petzold, A.: Measurements of ultrafine aerosol size distributions by a combination of diffusion screen separators and condensation particle counters, J. Aerosol Sci., 37, 577-597, doi:10.1016/j.jaerosci.2005.04.009, 2006.

Forster, P., Ramaswamy, V., Artaxo, P., Berntsen, T, Betts, R., Fahey, D.W., Haywood, J., Lean, J., Lowe, D.C., Myhre, G., Nganga, J., Prinn, R., Raga, G., Schulz, M., and Van Dorland, R.: Changes in Atmospheric Constituents and Radiative Forcing, in: Climate Change 2007: The Physical Science Basis, Contribution of Working Group I to the Fourth Assessment Report of the Intergovernmental Panel on Climate Change, edited by: Solomon, S., Qin, D., Manning, M., Chen, Z., Marquis, M., Averyt, K. B., Tignor, M., and Miller, H. L., Cambridge University Press, Cambridge, NY, USA, 143-145, 2007. 
Frieß, U., Wagner, T., Pundt, I., Pfeilsticker, K., and Platt, U.: Spectroscopic Measurements of Troposheric Iodine Oxide at Neumayer Station, Antarctica, Geophys. Res. Lett., 28, 1941-1944, doi:10.1029/2000GL012784, 2001.

Gabric, A. J., Shephard, J. M., Knight, J. M., Jones, G., and Trevena, A. J.: Correlations between the satellite-derived seasonal cycles of phytoplankton biomass and aerosol optical depth in the Southern Ocean: Evidence for the influence of sea ice, Global Biogeochem. Cycles, 19, GB4018, doi:10.1029/2005GB002546, 2005.

Ghil, M., Allen, M. R., Dettinger, D., Die, K., Kondrashov, D., Mann, M. E., Robertson, A. W., Saunders, A., Tian, Y., Varadi, F., and Yiou, P.: Advanced spectral methods for climatic time series, Rev. Geophys., 40, 1-41, doi:10.1029/2000RG000092, 2002.

Gras, J. L.: Baseline atmospheric condensation nuclei at Cape Grim 1977-1987, J. Atmos. Chem., 11, 89-106, 1990.

Gras, J. L.: Condensation nucleus size distribution at Mawson, Antarctica: Seasonal cycle, Atmos. Environ., 27, 1417-1425, 1993.

Gras, J. L.: CN, CCN and particle size in Southern Ocean air at Cape Grim, Atmos. Res., 35, 233-251, 1995.

Handorf, D.: Zur Parametrisierung der stabilen atmosphärischen Grenzschicht über einem antarktischen Schelfeis, in: Reports on Polar and Marine Research, 204, edited by: Riemann, F., AlfredWegener-Inst. for Polar and Marine Res., Bremerhaven, 1996.

Hara, K., Osada, K., Nishita-Hara, C., and Yamanouchi, T.: Seasonal variations and vertical features of aerosol particles in the Antarctic troposphere, Atmos. Chem. Phys., 11, 5471-5484, doi:10.5194/acp-11-5471-2011, 2011a.

Hara, K., Osada, K., Nishita-Hara, C., Yabuki, M., Hayashi, M., Yamanouchi, T., Wada, M., and Shiobara, M.: Seasonal features of ultrafine particle volatility in the coastal Antarctic troposphere, Atmos. Chem. Phys., 11, 9803-9812, doi:10.5194/acp-11-98032011, 2011 b.

Hatzianastassiou, N., Katsoulis, B., and Vardavas, I.: Global distribution of aerosol direct radiative forcing in the ultraviolet and visible arising under clear skies, Tellus, 56, 51-71, 2004.

Haywood, J. and Boucher, O.: Estimates of the direct and indirect radiative forcing due to tropospheric aerosols: A review, Rev. Geophys., 38, 513-543, 2000.

Heintzenberg, J., Birmili, W., Wiedensohler, A., Nowak, A., and Tuch, T.: Structure, variability and persistence of the submicrometre marine aerosol, Tellus, 56, 357-367, 2004.

Hirsch, R. M., Slack, J. R., and Smith, R. A.: Techniques of trend analysis for monthly water quality data, Water Resour. Res., 18, 107-121, 1982.

Ito, T.: Study of background aerosols in the Antarctic Troposphere, J. Atmos. Chem. 3, 69-91, 1985.

Ito, T.: Size distribution of Antarctic submicron aerosols, Tellus, 45, 145-159, 1993.

Jaenicke, R., Dreiling, V., Lehmann, E., Koutsenoguii, P. K., and Stingl, J.: Condensation nuclei at the German Antarctic Station, Georg von Neumayer, Tellus, 44, 311-317, 1992.

Jourdain, B. and Legrand, M.: Seasonal variations of atmospheric dimethylsulfide, dimethylsulfoxide, sulfur dioxide, methanesulfonate and non-sea-salt sulfate at Dumont d'Urville (coastal Antarctica, December 1998 to July 1999), J. Geophys. Res., 106, 14391-14408, 2001.
Kerminen, V. M. and Kulmala, M.: Analytical formulae connecting the "real" and the "apparent" nucleation rate and the nuclei number concentration for atmospheric nucleation events, Aerosol Sci., 33, 609-622, 2002.

König-Langlo, G., King, J. C., and Pettré, P.: Climatology of the three coastal Antarctic stations Dumont d'Urville, Neumayer and Halley, J. Geophys. Res., 103, 10935-10946, 1998.

Koponen, I. K., Virkkula, A., Hillamo, R., Kerminen, V.-M., and Kulmala, M.: Number size distribution and concentrations of the continental summer aerosol in Queen Maud Land, Antarctica, J. Geophys. Res., 108, 4587, doi:10.1029/2003JD003614, 2003.

Korhonen, H., Carslaw, K. S., Spracklen, D. V., Mann, G. W., and Woodhouse, M. T.: Influence of oceanic dimethyl sulfide emissions on cloud condensation nuclei concentrations and seasonality over the remote Southern Hemisphere ocean: A global model study, J. Geophys. Res., 113, D15204, doi:10.1029/2007JD009718, 2008.

Krueger, A. J., Walter, L. S., Bhartia, P. K., Schnetzler, C. C., Krotkov, N. A., Sprod, I., and Bluth, G. J. S.: Volcanic sulfur dioxide measurements from the total ozone mapping spectrometer instruments, J. Geophys. Res., 100, 14057-14076, 1995.

Kulmala, M., Pirjola, L., and Mäkelä, J. M.: Stable sulphate clusters as a source of new atmospheric particles, Nature, 404, 66-69, 2000.

Kulmala, M., Hämeri, K., Aalto, P. P., Mäkela, J. M., Pirjola, L., Douglas Nilsson, E., Buzorius, G., Rannik, Ü., Dal Maso, M., Seidl, W., Hoffman, T., Janson, R., Hansson, H.-C., Viisanen, Y., Laaksonen, A., and O'Dowd, C. D.: Overview of the international project on biogenic aerosol formation in the boreal forest (BIOFOR), Tellus, 53, 324-343, 2001.

Kulmala, M., Vehkamäki, H., Petäjä, T., Dal Maso, M., Lauri, A., Kerminen, V.-M., Birmili, W., and McMurry, P. H.: Formation and growth rates of ultrafine atmospheric particles: a review of observations, Aerosol Sci., 35, 143-176, doi:10.1016/j.jaerosci.2003.10.003, 2004.

Kulmala, M., Riipinen, I., Sipilä, M., Manninen, H. E., Petäjä, T., Junninen, H., Dal Maso, M., Mordas, G., Mirme, A., Vana, M., Hirsikko, A., Laakso, L., Harrison, R. M., Hanson, I., Leung, C., Lehtinen, K. E. J., and Kerminen, V.-M.: Towards Direct Measurements of Atmospheric Nucleation, Science, 318, 89-92, 2007.

Lana, A., Bell, T. G., Simó, R., Vallina, S. M., and Ballabrera-Poy, J.: An updated climatology of surface dimethylsulfide concentrations and emission fluxes in the global ocean, Global Biochem. Cycles, 25, GB1004, doi:10.1029/2010GB003850, 2011.

Legrand, M. and Wagenbach, D.: Impact of the Cerro Hudson and Pinatubo volcanic eruptions on the Antarctic air and snow chemistry, J. Geophys. Res., 104, 1581-1596, 1998.

Mauldin III, R. L., Kosciuch, E., Henry, B., Eisele, F. L., Shetter, R., Lefer, B., Chen, G., Davis, D., Huey, G., and Tanner, D.: Measurements of $\mathrm{OH}, \mathrm{HO}_{2}+\mathrm{RO}_{2}, \mathrm{H}_{2} \mathrm{SO}_{4}$, and MSA at the South Pole during ISCAT 2000, Atmos. Environ., 38, 54235437, 2004.

McCormick, M. P., Thomason, L. W., and Trepte, C. R.: Atmospheric effects of the Mt. Pinatubo eruption, Nature, 373, 399404, 1995.

McFiggans, G., Bale, C. S. E., Ball, S. M., Beames, J. M., Bloss, W. J., Carpenter, L. J., Dorsey, J., Dunk, R., Flynn, M. J., Furneaux, K. L., Gallagher, M. W., Heard, D. E., Hollingsworth, A. M., 
Hornsby, K., Ingham, T., Jones, C. E., Jones, R. L., Kramer, L. J., Langridge, J. M., Leblanc, C., LeCrane, J.-P., Lee, J. D., Leigh, R. J., Longley, I., Mahajan, A. S., Monks, P. S., Oetjen, H., Orr-Ewing, A. J., Plane, J. M. C., Potin, P., Shillings, A. J. L., Thomas, F., von Glasow, R., Wada, R., Whalley, L. K., and Whitehead, J. D.: Iodine-mediated coastal particle formation: an overview of the Reactive Halogens in the Marine Boundary Layer (RHaMBLe) Roscoff coastal study, Atmos. Chem. Phys., 10, 2975-2999, doi:10.5194/acp-10-2975-2010, 2010.

Minikin, A., Legrand, M., Hall, J., Wagenbach, D., Kleefeld, C., Wolff, E., Pasteur, E. C., and Ducroz, F.: Sulfur-containing species (sulfate and methanesulfonate) in coastal Antarctic aerosol and precipitation, J. Geophys. Res., 103, 10975-10990, 1998.

O’Dowd, C. D., Lowe, J. A., Smith, M. H., Davidson, B., Hewitt, C. N., and Harrison, R. M.: Biogenic sulphur emissions and inferred non-sea-salt-sulphate cloud condensation nuclei in and around Antarctica, J. Geophys. Res., 102, 12839-12854, 1997.

O’Dowd, C. D., Hämeri, K., Mäkelä, J. M., Pirjola, L., Kulmala, M., Jennings, S. G., Berresheim, H., Hansson, H.-C., de Leeuw, G., Kunz, G. J., Allen, A. G., Hewitt, C. N., Jackson, A., Viisanen, Y., and Hoffmann, T.: A dedicated study of New Particle Formation and Fate in the Coastal Environment (PARFORCE): Overview of objectives and achievements, J. Geophys. Res., 107, 8108, doi:10.1029/2001JD000555, 2002a.

O’Dowd, C. D., Jimenez, J. L., Bahreini, R., Flagan, R. C., Seinfeld, J. H., Hämeri, K., Pirjola, L., Kulmala, M., Jennings, S. G., and Hoffmann, T.: Marine aerosol formation from biogenic iodine emissions, Nature, 417, 632-636, doi:10.1038/nature00775, 2002b.

Park, J., Sakurai, H., Vollmers, K., and McMurry, P. H.: Aerosol size distributions measured at South Pole during ISCAT, Atmos. Environ., 38, 5493-5500, doi:10.1016/j.atmosenv.2002.12.001, 2004.

Percival, D. B. and Walden, A. T.: Spectral Analysis for Physical Applications, Cambridge Univ. Press, New York, 583 pp., 1993.

Piel, C., Weller, R., Huke, M., and Wagenbach, D.: Atmospheric methane sulfonate and non-sea salt sulphate records at the EPICA deep-drilling site in Dronning Maud Land, Antarctica, J. Geophys. Res., 111, D03304, doi:10.1029/2005JD006213, 2006.

Preunkert, S., Legrand, M., Jourdain, B., Moulin, C., Belviso, S., Kasamatsu, N., Fukuchi, M., and Hirawake, T.: Interannual variability of dimethylsulfide in air and seawater and its atmospheric oxidation by-products (methanesulfonate and sulfate) at Dumont d'Urville, coastal Antarctica (1999-2003), J. Geophys. Res., 112, D06306, doi:10.1029/2006JD0075857, 2007.

Raes, F.: Entrainment of free tropospheric aerosols as a regulating mechanism for cloud condensation nuclei in the remote marine boundary layer, J. Geophys. Res., 100, 2893-2903, 1995.

Raes, F., Van Dingenen, R., Vignati, E., Wilson, J., Putaud, J.-P., Seinfeld, J. H., and Adams, P.: Formation and cycling of aerosols in the global troposphere, Atmos. Environ., 34, 4215-4240, 2000.

Ramanathan, V., Crutzen, P. J., Kiehl, J. T., and Rosenfeld, D.: Aerosols, Climate, and the Hydrological Cycle, Science, 294, 2119-2124, 2001.

Rathke, C., Notholt, J., Fischer, J., and Herber, A.: Properties of coastal Antarctic aerosol from combined FTIR spectrometer and sun photometer measurements, Geophys. Res. Lett., 29, 2131, doi:10.1029/2002GL015395, 2002.
Read, K. A., Lewis, A. C., Bauguitte, S., Rankin, A. M., Salmon, R. A., Wolff, E. W., Saiz-Lopez, A., Bloss, W. J., Heard, D. E., Lee, J. D., and Plane, J. M. C.: DMS and MSA measurements in the Antarctic Boundary Layer: impact of BrO on MSA production, Atmos. Chem. Phys., 8, 2985-2997, doi:10.5194/acp-82985-2008, 2008.

Robinson, E., Bodhaine, B. A., Komhyr, W. D., Oltmans, S. J., Steele, L. P., Tans, P., and Thompson, T. M.: Long-term air quality monitoring at the South Pole by the NOAA program Geophysical Monitoring for Climate Change, Rev. Geophys., 26, 6380, 1998.

Russell, P. B., Livingston, J. M., Pueschel, R. F., Baumann, J. J., Pollack, J. B., Brooks, S. L., Hamill, P., Thomason, L. W., Stowe, L. L., Deshler, T., Dutton, E. G., and Bergstrom, R. W.: Global to microscale evolution of the Pinatubo volcanic aerosol derived from diverse measurements and analyses, J. Geophys. Res., 101, 18745-18763, 1996.

Saiz-Lopez, A., Mahajan, A. S., Salmon, R. A., Bauguitte, J.-B., Jones, A. E., Roscoe, H. K., and Plane, J. M. C.: Boundary Layer Halogens in Coastal Antarctica, Science, 317, 348-351, doi:10.1126/science.1141408, 2007.

Samson, J. A., Barnard, S. C., Obremski, J. S., Riley, D. C., Black, J. J., and Hogan, A. W.: On the systematic variation in surface aerosol concentration at South Pole, Atmos. Res., 25, 385-396, 1990.

Shaw, G. E.: Antarctic aerosols: A review, Rev. Geophys., 26, 89$112,1988$.

Shirsat, S. V. and Graf, H. F.: An emission inventory of sulfur from anthropogenic sources in Antarctica, Atmos. Chem. Phys., 9, 3397-3408, doi:10.5194/acp-9-3397-2009, 2009.

Simpson, W. R., von Glasow, R., Riedel, K., Anderson, P., Ariya, P., Bottenheim, J., Burrows, J., Carpenter, L. J., Frie, U., Goodsite, M. E., Heard, D., Hutterli, M., Jacobi, H.-W., Kaleschke, L., Neff, B., Plane, J., Platt, U., Richter, A., Roscoe, H., Sander, R., Shepson, P., Sodeau, J., Steffen, A., Wagner, T., and Wolff, E.: Halogens and their role in polar boundary-layer ozone depletion, Atmos. Chem. Phys., 7, 4375-4418, doi:10.5194/acp-74375-2007, 2007.

Sipilä, M., Berndt, T., Petäjä, T, Brus, D., Vanhanen, J., Stratmann, F., Patokoski, J., Mauldin III, R. L., Hyvärinen, A.P., Lihavainen, H., and Kulmala, M.: The Role of Sulfuric Acid in Atmospheric Nucleation, Science, 327, 1243-1246, doi:10.1126/science.1180315, 2010.

Solomon, S.: Stratospheric ozone depletion: A review of concepts and history, Rev. Geophys., 37, 275-316, 1999.

Spracklen, D. V., Carslaw, K. S., Merikanto, J., Mann, G. W., Reddington, C. L., Pickering, S., Ogren, J. A., Andrews, E., Baltensperger, U., Weingartner, E., Boy, M., Kulmala, M., Laakso, L., Lihavainen, H., Kivekäs, N., Komppula, M., Mihalopoulos, N., Kouvarakis, G., Jennings, S. G., O’Dowd, C., Birmili, W., Wiedensohler, A., Weller, R., Gras, J., Laj, P., Sellegri, K., Bonn, B., Krejci, R., Laaksonen, A., Hamed, A., Minikin, A., Harrison, R. M., Talbot, R., and Sun, J.: Explaining global surface aerosol number concentrations in terms of primary emissions and particle formation, Atmos. Chem. Phys., 10, 4775-4793, doi:10.5194/acp-10-4775-2010, 2010.

Steig, E. J., Schneider, D. P., Rutherford, S. D., Mann, M. E., Cosimo, J. C., and Shindell, D. T.: Warming of the Antarctic ice-sheet surface since the 1957 International Geophysical Year, 
Nature, 457, 459-463, doi:10.1038/nature07669, 2009.

Stolzenburg, M. R. and McMurry, P. H.: An ultrafine aerosol condensation nucleus counter, Aerosol Sci. Technol., 14, 48-65, 1991.

Stull, R. B.: An Introduction to Boundary Layer Meteorology, Kluwer Academic Publishers, Dordrecht, Dordrecht, 175-180, 1988.

Teinilä, K., Kerminen, V.-M., and Hillamo, R.: A study of sizesegregated aerosol chemistry in the Antarctic atmosphere, J. Geophys. Res., 105, 3893-3904, 2000.

Thompson, D. W. J. and Solomon, S.: Interpretation of recent southern Hemisphere climate change, Nature, 296, 895-899, 2002.

Virkkula, A., Hirsikko, A., Vana, M., Aalto, P. P., Hillamo, R., and Kulmala, M.: Charged particle size distributions and analysis of particle formation events at the Finnish Antarctic research station Abao, Boreal Environ. Res., 12, 397-408, 2007.

von Glasow, R. and Crutzen, P. J.: Model study of multiphase DMS oxidation with a focus on halogens, Atmos. Chem. Phys., 4, 589608, doi:10.5194/acp-4-589-2004, 2004.

Wagenbach, D., Görlach, U., Moser, K., and Münnich, K. O.: Coastal Antarctic aerosol: the seasonal pattern of its chemical composition and radionuclide content, Tellus, 40, 423-436, 1988.
Wagenbach, D.: Coastal Antarctica: Atmospheric chemical composition and atmospheric transport, in: Chemical Exchange between the Atmosphere and polar snow, edited by: Wolff, E. W. and Bales, R. C., NATO ASI Series, Springer-Verlag Berlin Heidelberg, 43, 173-199, 1996.

Wehner, B., Philippin, S., and Wiedensohler, A.: Design and calibration of a thermodenuder with an improved heating unit to measure the size dependent volatile fraction of aerosol particles, Aerosol Sci., 33, 1087-1093, 2002.

Weller, R. and Lampert, A.: Optical properties and sulfate scattering efficiency of boundary layer aerosol at coastal Neumayer Station, Antarctica, J. Geophys. Res., 113, D16208, doi:10.1029/2008JD009962, 2008.

Weller, R., Wöltjen, J., Piel, C., Resenberg, R., Wagenbach, D., König-Langlo, G., and Kriews, M.: Seasonal variability of crustal and marine trace elements in the aerosol at Neumayer station, Antarctica, Tellus, 60, 742-752, doi:10.1111/j.16000889.2008.00372.x, 2008.

Weller, R., Wagenbach, D, Legrand, M., Elsässer, C., TianKunze, X., and König-Langlo, G.: Continuous $25 \mathrm{yr}$ aerosol records at coastal Antarctica - 1: inter-annual variability of ionic compounds and links to climate indices, Tellus, 63, 901-919, doi:10.1111/j.1600-0889.2011.00542.x, 2011. 